Journal of Social Sciences 4 (4): 255-263, 2008

ISSN 1549-3652

(C) 2008 Science Publications

\title{
Financial Service of Wealth Management Banking: Balanced Scorecard Approach
}

\author{
Cheng-Ru Wu, Chin-Tsai Lin and Pei-Hsuan Tsai \\ Graduate Institute of Business and Management, Yuanpei University, \\ 306 Yuanpei St., Hsin Chu 30015, Republic of China, Taiwan
}

\begin{abstract}
Problem Statement: There are four main banking business sectors in Taiwan, involving the areas of consumer, corporate, wealth management, and investment banking. The wealth management banking sector is actively promoted for reaping a risk-free premium. In the proposed model, the dimensions of financial services for wealth management banks have been taken from four perspectives derived from balanced scorecard approach, viz. finance, customer, internal business, learning and growth. Approach: The organizational performance of wealth management banks in Taiwan is evaluated by applying the Analytical Hierarchy Process (AHP) and the Technique for Order Preference by Similarity to Ideal Solution (TOPISI). Results: Table 6 shows the relative weights of the four banks based on the results of from AHP, as well as the relative weights from TOPSIS. In the demonstrated example, Bank $\mathrm{C}$ should be perfect because it has the largest relative weights (Bank $\mathrm{C}=0.288$ and 0.539 , from AHP and TOPSIS in Table 8). In Table 6, Summary of the TOPSIS $\mathrm{C}_{\mathrm{i}}^{*}$ with respect to wealth management banks: A (0.482), B (0.269), C (0.539) and D (0.294). C performs the best. Conclusion: Importantly, the proposed model can benefit the banking sector in assessing the organizational performance of wealth management banks, making it highly applicable for bank managers and financial sector analysts.
\end{abstract}

Key words: Organizational performance, wealth management, AHP, TOPSIS, balanced scorecard

\section{INTRODUCTION}

Taiwan's economic and financial markets have experienced dramatic changes in recent years. Additionally, the organizational structure of the wealth management service sector has improved as banks have implemented management practices that have helped to increase their competitiveness. In such an intensive environment, selecting a performance measurement of wealth management banking has become a priority. During the process of selecting a wealth management bank, apart from legal issues, policymakers and business groups seldom consider potential factors that could impact a bank's competitiveness.

Many business organizations have found the Balanced Scorecard to be a valuable tool in performance and strategic management $t^{[7-10]}$. The objective of this study is to examine the value of Balanced Scorecard in the organizational performance of wealth management banks and to describe an analytic hierarchy framework that can be used to evaluate scorecards of departments and programs within wealth management banks and the organizational performance of wealth management banks as a whole.

The Technique for Ordering Preference by Similarity to the Ideal Solution (TOPSIS) was first developed by ${ }^{[2]}$, based on the concept that the selected alternative should have the shortest distance from the positive ideal solution and the farthest from the negative-ideal solution for solving the MCDM problem. Thus, the best alternative should not only have the shortest distance from the positive ideal solution, but also the longest distance from the negative ideal solution. In short, the ideal solution comprises all of the optimum criteria values, whereas the negative ideal solution comprises all the least optimal criteria values. However, the results vary according to period, modeling and approach. In the proposed AHP model, the dimensions of the organizational performance for the wealth management banks have been taken from the four perspectives of the Balanced Scorecard, thus balancing as well as linking the financial and nonfinancial, tangible and intangible, internal and external factors. Therefore, the proposed framework provides a

Corresponding Author: Cheng-Ru Wu, Graduate Institute of Business and Management, Yuanpei University, 306 Yuanpei St., Hsin Chu 30015, Republic of China, Taiwan 
holistic approach to the selected Multi-Criteria Decision-Making (MCDM) problem for wealth management banks. Next, a case identifies proposal model using AHP and the TOPSIS technique to evaluate wealth management banks' organizational performance. This proposal further combines the concepts of the AHP and TOPSIS models to evaluate and rank wealth management bank performance. The AHP and TOPSIS-based decision-making method for constructing an evaluation method can provide bank decision makers or administrators with a valuable reference for evaluating the organizational performance. Importantly, the proposed model can provide Taiwan's bank accreditation policy a reference material, making it highly applicable for bank administrators and financial sector analysts.

\section{MATERIALS AND METHODS}

The AHP Methodology: Analytic Hierarchy Process (AHP), which is a technique of Multi-Criteria Decision Making (MCDM), was developed by Saaty in 2000. AHP is used to solve complex decision-making problems in different areas, such as maintenance selection problem ${ }^{[16]}$, selection of location $^{[13,14,15]}$, measuring performance ${ }^{[1,14]}$, allocating resources ${ }^{[17]}$, choosing the best policy after finding a set of alternatives ${ }^{[18]}$. As a decision method that decomposes a complex multi-criteria decision problem into a hierarchy ${ }^{[11]}$, AHP is also a measurement theory that prioritizes the hierarchy and consistency of judgmental data provided by a group of decision makers. AHP incorporates the evaluations of all decision makers into a final decision, without having to elicit their utility functions on subjective and objective criteria, by pairwise comparisons of the alternatives ${ }^{[12]}$.

The TOPSIS Methodology: The TOPSIS was first proposed by Hwang and Yoon ${ }^{[2]}$. The underlying logic of TOPSIS is to define the ideal solution and the negative ideal solution. The ideal solution is the solution that maximizes the benefit criteria and minimizes the cost criteria; whereas the negative ideal solution maximizes the cost criteria and minimizes the benefit criteria. The optimal alternative is the one, which is closest to the ideal solution and farthest to the negative ideal solution. The ranking of alternatives in TOPSIS is based on 'the relative similarity to the ideal solution', which avoids from the situation of having same similarity to both ideal and negative ideal solutions.

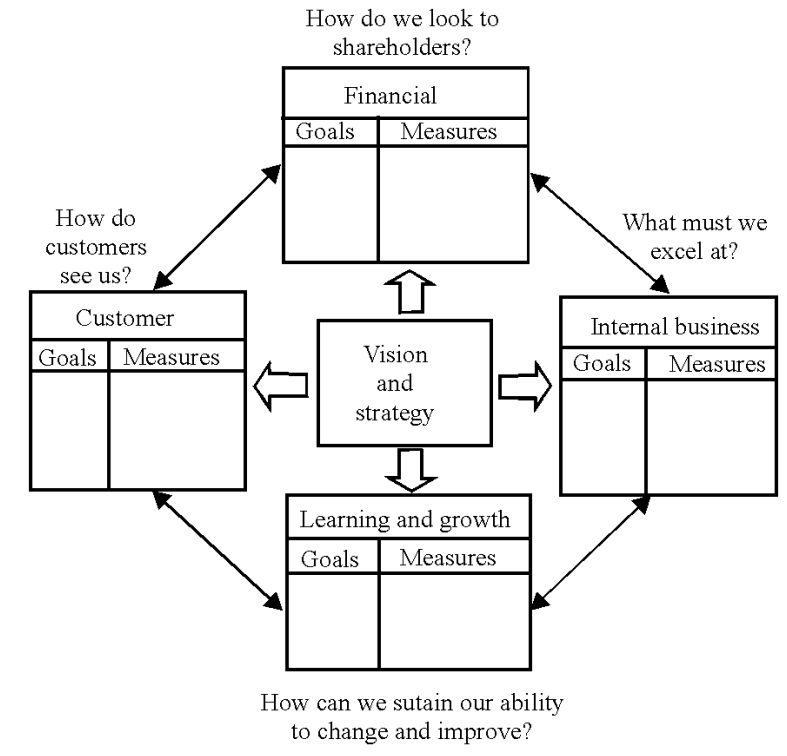

Fig. 1: Four perspectives of balanced scorecard

The balanced scorecard: Kaplan and Norton ${ }^{[5,6,8]}$ presented the Balanced Scorecard concept in a series of articles published in the Harvard Business Review. They argued that traditional financial accounting measures such as return-on-investment and payback period analysis ${ }^{[4,8]}$ offer a narrow and incomplete picture of business performance and that reliance on such data hinders the creation of future business value. Accordingly, they suggest that financial measures can be supplemented with additional ones that reflect customer satisfaction, internal business processes and the ability to learn and grow. The Balanced Scorecard was designed to complement "financial measures of past performance with measures of the drivers of future performance, ${ }^{,[8]}$.

Of the four key performance perspectives of the Balanced Scorecard, only one involves standard financial performance indicators, whereas the other three involve non-financial performance measurement perspectives: customer satisfaction, internal business processes and learning and growth capacities. These four perspectives constitute the framework of the Balanced Scorecard (Fig. 1).

Evaluation model: The evaluation procedure of this study consists of several steps as shown in Fig. 2. The first step is to identify the multiple criteria that are considered in the decision making process for the decision makers to make an objective and unbiased decision. The Delphi method is adopted here not only to accumulate expert opinions, but also to identify the 


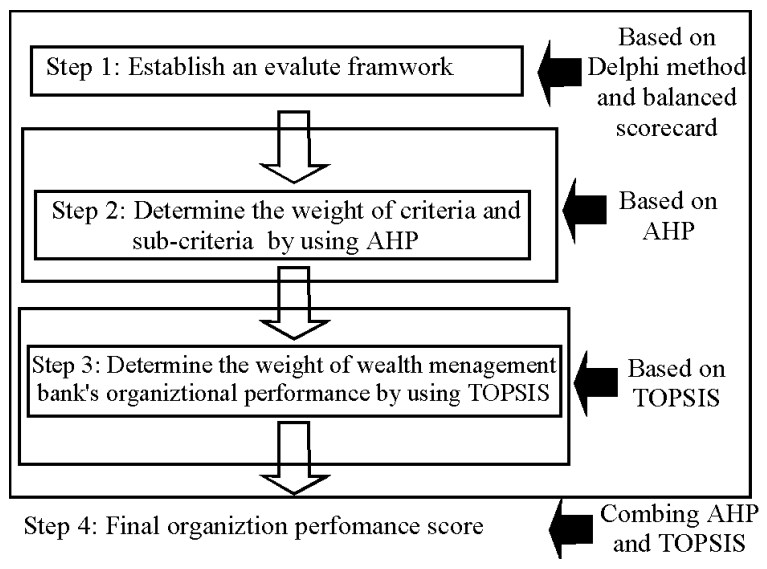

Fig. 2: AHP and TOPSIS Measurement Processes for Wealth Management Bank's Organizational Performance

determinants of the integrated marketing communication-based model. After constructing a criteria framework, the criteria weights can be calculated by using AHP. Finally, we conduct a TOPSIS approach to achieve the final ranking results. The detailed descriptions of each step are elaborated in each of the following sub-criteria.

Establish an evaluate model and define the evaluative criteria: Using the Delphi method, a consensus among experts on establishing a model can be reached. The ultimate goal of evaluating the ideal organizational performance can be achieved, following the identification of four evaluation criteria, nineteen sub-criteria and finally, the alternatives (Fig. 3).

The evaluation criteria and sub-criteria used to evaluate the organizational performance are defined as follows:

Financial perspective: Financial perspective refers to a wealth management bank's revenue during the operation time, including handling charge/revenue, customer market share ratio, capacity for profitability and management assets (suggested by bank administrators and academicians):

- Handling charge/revenue: Wealth management bank's revenue gained by selling the customer's product

- Customers market share ratio: Reflects the proportion of business in a given market (in terms of the number of customers, dollars spent, or unit volume sold) that a business unit sells
- Capacity for profitability: The various products and projects created by wealth management banks that serve to increase their capacity for profitability

- Management assets: Management assets are a very important factor in Taiwan's wealth management banking sector

Customer perspective: Factors involving the customers of wealth management banks include customer acquisition, VIP-certified financial services (suggested by bank administrators and academicians), customer profitability, customer confidence and customer retention ${ }^{[8]}$.

- Customer acquisition: Measures, in absolute or relative terms, the rate at which a business unit attracts or wins new customers or business.

- VIP-certified financial service: The provision to customers of complete VIP-certified financial services

- Customer profitability: Measures the net profit of a customer, or of a segment, after allowing for the unique expenses required to support that customer or segment

- Customer confidence: Wealth managers improve the VIP service for new customers and assure them confidentiality

- Customer retention: Tracks, in absolute or relative terms, the rate at which a business unit retains or maintains ongoing relationships with its customers

Internal business process perspective: Wealth management bank performance measurement, organization, management practices and competitors all influence the following factors: lead in innovation system programming, certified financial integration platform for professionals, operating quality for a group of customers, internal customer satisfaction and management stratum support (suggested by bank administrators and academicians).

- Lead in innovation system programming: Measures how well a wealth management bank accedes to innovation system programming in accordance with the wealth manager's professional knowledge and ability

- Certified financial integration platform for professionals: The wealth management bank provides the certified financial integration platform for professional VIP customers

- Operational quality for a group of customers: The administration of the operational quality for a 


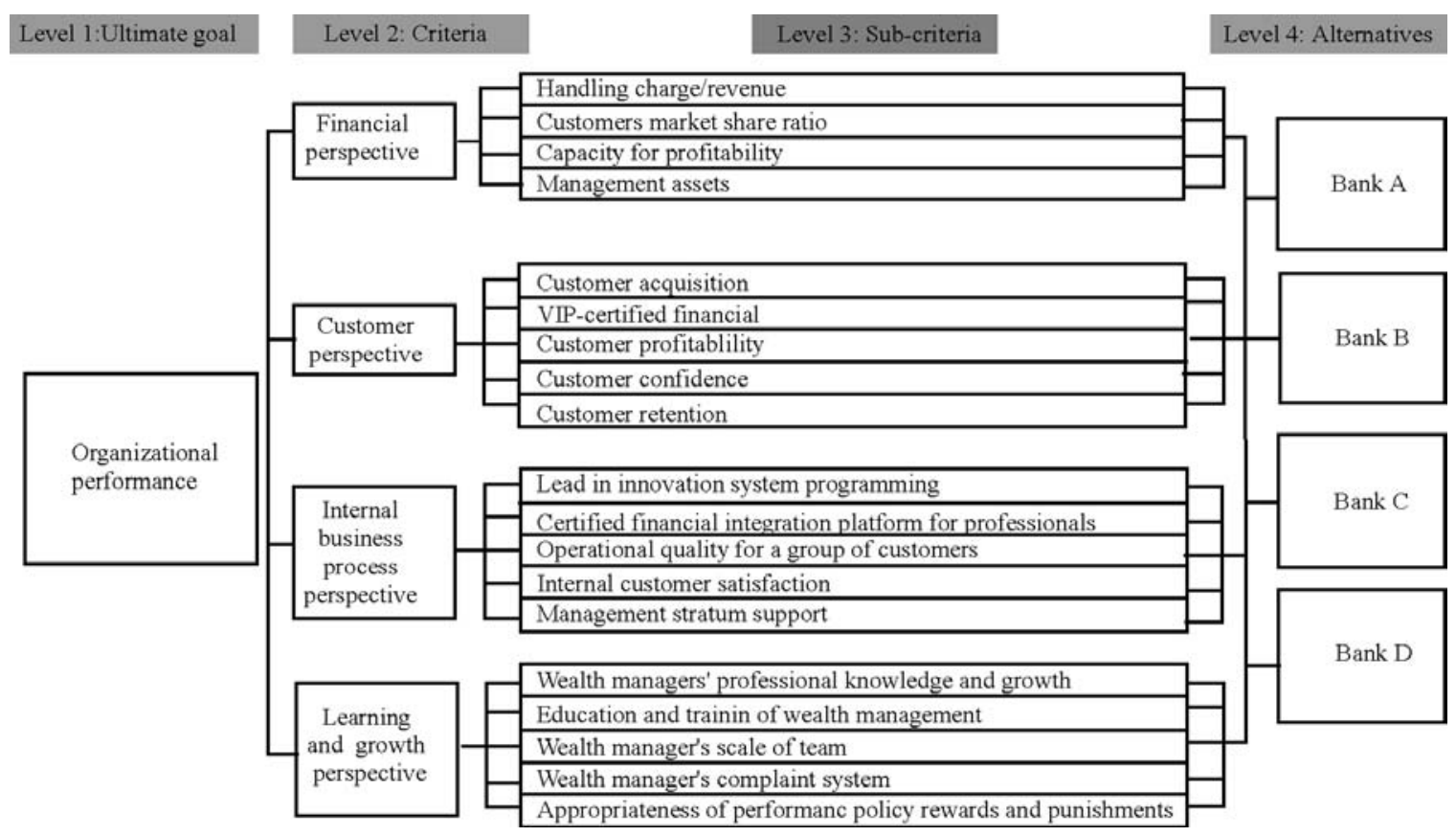

Fig. 3: Wealth Management Bank's organizational performance model

- $\quad$ group of customers requires professional CEO and wealth managers

- Internal customer satisfaction: The internal customer satisfaction index was constructed through monthly surveys of randomly selected customers in the wealth management bank's targeted segments

- Management stratum support: To obtain the executive manager's support

Learning and growth perspective: The factors comprising the learning and growth perspective include wealth manager's professional knowledge and growth, education and training of wealth management team, wealth manager's scale of team, wealth manager's complaint system and appropriateness of performance policy for rewards and punishments.

- Wealth managers' professional knowledge and growth: The wealth management bank develops the wealth manager's professional knowledge and techniques

- Education and training of wealth management team: This includes wealth management knowledge, the use of teleconferencing and the attainment of basic professional certificates

- Wealth manager's scale of team: The bank provides a complete wealth manager's scale of team for the customer service system
- Wealth managers' complaint system: The banks provide the complaint system for wealth managers

- Appropriateness of performance policy rewards and punishments: Herzberg's motivation theory (1966) argued that there must be a link among striving, performance and remuneration. Academicians have also indicated that linking bounty, remuneration and performance to the performance bonus system can enable wealth managers to work more effectively with increased motivation

Determine the weight of criteria by using AHP: As a decision method that decomposes a complex multicriteria decision problem into a hierarchy ${ }^{[11]}$, AHP is also a measurement theory that prioritizes the hierarchy and consistency of judgmental data provided by a group of decision makers. AHP incorporates the evaluations of all decision makers into a final decision ${ }^{[1,3,14,15]}$, without having to elicit their utility functions on subjective and objective criteria, by pair-wise comparisons of the alternatives ${ }^{[12]}$. AHP is made in the framework of a matrix and a local priority vector can be derived as an estimate of relative importance associated with the elements (or components) being compared by solving the following formulae:

$\mathrm{A} \cdot \mathrm{w}=\lambda_{\text {max }} \cdot \mathrm{w}$ 
Where:

$\mathrm{A}=$ The matrix of pair-wise comparison

$\mathrm{w}=$ The eigenvector

$\lambda_{\max }=$ The largest Eigenvalue of $\mathrm{A}$

Saaty ${ }^{[11]}$ proposed utilizing Consistency Index (CI) and Consistency Ratio (CR) to verify the consistency of the comparison matrix. $\mathrm{CI}$ and $\mathrm{RI}$ are defined as follows:

$$
\begin{aligned}
& \text { C.I. }=\frac{\lambda_{\max }-\mathrm{n}}{\mathrm{n}-1} \\
& \mathrm{CR}=\frac{\mathrm{CI}}{\mathrm{RI}}
\end{aligned}
$$

where, RI represents the average consistency index over numerous random entries of same order reciprocal matrices. If $\mathrm{CR} \leq 0.1$, the estimate is accepted; otherwise, a new comparison matrix is solicited until $\mathrm{CR} \leq 0.1$.

Determine the wealth management banks' organizational performance by using TOPSIS: The TOPSIS was first proposed by ${ }^{[2]}$. The underlying logic of TOPSIS is to define the ideal solution and the negative ideal solution. The ideal solution is the solution that maximizes the benefit criteria and minimizes the cost criteria; whereas the negative ideal solution maximizes the cost criteria and minimizes the benefit criteria. The optimal alternative is the one, which is closest to the ideal solution and farthest to the negative ideal solution. The ranking of alternatives in TOPSIS is based on 'the relative similarity to the ideal solution', which avoids from the situation of having same similarity to both ideal and negative ideal solutions. The calculation processes of the method are as following:

Establish a Decision (D) matrix for alternative performance:

$$
\mathrm{D}=\frac{\mathrm{A}_{1}}{\mathrm{~A}_{2}} \begin{gathered}
\mathrm{A}_{\mathrm{i}} \\
\vdots \\
\mathrm{A}_{\mathrm{m}}
\end{gathered}\left[\begin{array}{cccccc}
\mathrm{X}_{11} & \mathrm{X}_{12} & \cdots & \cdots & \mathrm{X}_{1 \mathrm{j}} & \mathrm{X}_{1 \mathrm{n}} \\
\mathrm{X}_{21} & \mathrm{X}_{22} & \cdots & \cdots & \mathrm{X}_{2 \mathrm{j}} & \mathrm{X}_{2 \mathrm{n}} \\
\vdots & \vdots & \cdots & \vdots & \vdots & \vdots \\
\mathrm{X}_{\mathrm{i} 1} & \mathrm{X}_{\mathrm{i} 2} & \vdots & \vdots & \mathrm{X}_{\mathrm{ij}} & \mathrm{X}_{\mathrm{in}} \\
\vdots & \vdots & \cdots & \vdots & \vdots & \vdots \\
\mathrm{X}_{\mathrm{m} 1} & \mathrm{X}_{\mathrm{m} 2} & \cdots & \cdots & \mathrm{X}_{\mathrm{mj}} & \mathrm{X}_{\mathrm{mn}}
\end{array}\right] .
$$

Where:

$\mathrm{A}_{\mathrm{i}}=$ The possible alternatives, $\mathrm{i}=1, \ldots, \mathrm{m}$

$\mathrm{X}_{\mathrm{j}}=$ Attributes or criteria relating to alternative performance, $\mathrm{j}=1, \ldots, \mathrm{n}$
$X_{i j}=$ a crisp value indicating the performance rating of each alternative $A_{i}$ with respect to each criterion $\mathrm{X}_{\mathrm{j}}$.

Normalizing the D matrix: Calculate the normalized decision matrix $R\left(=\left[r_{i j}\right]\right)$. The normalized value $r_{i j}$ is calculated as:

$$
r_{i j}=\frac{X_{i j}}{\sqrt{\sum_{j=1}^{n} X_{i j}^{2}}}, j=1, \ldots, n ; i=1, \ldots, m
$$

Create the weighted normalized performance matrix: A set of weights $w=\left(w_{1}, w_{2}, \ldots w_{n}\right), \sum_{j=1}^{n} w_{j}=1$, from the ANP is accommodated weight. This matrix can be calculated by multiplying each column of the $R$ with its associated weight $\mathrm{w}_{\mathrm{j}}$. Therefore, the weighted normalized decision matrix $V$ is equal to:

$$
\begin{aligned}
\mathrm{V} & =\left[\begin{array}{cccccc}
\mathrm{V}_{11} & \mathrm{~V}_{12} & \cdots & \mathrm{V}_{1 \mathrm{j}} & \cdots & \mathrm{V}_{\mathrm{ln}} \\
\vdots & \vdots & & \vdots & & \vdots \\
\mathrm{V}_{\mathrm{i} 1} & \mathrm{~V}_{\mathrm{i} 2} & \cdots & \mathrm{V}_{\mathrm{ij}} & \cdots & \mathrm{V}_{\mathrm{in}} \\
\vdots & \vdots & & \vdots & & \vdots \\
\mathrm{V}_{\mathrm{m} 1} & \mathrm{~V}_{\mathrm{m} 2} & \cdots & \mathrm{V}_{\mathrm{mj}} & \cdots & \mathrm{V}_{\mathrm{mn}}
\end{array}\right] \\
& =\left[\begin{array}{cccccc}
\mathrm{w}_{1} \mathrm{r}_{11} & \mathrm{w}_{2} \mathrm{r}_{12} & \cdots & \mathrm{w}_{\mathrm{j}} \mathrm{r}_{\mathrm{ij}} & \cdots & \mathrm{w}_{\mathrm{n}} \mathrm{r}_{1 \mathrm{n}} \\
\vdots & \vdots & & \vdots & & \vdots \\
\mathrm{w}_{1} \mathrm{r}_{\mathrm{i} 1} & \mathrm{w}_{2} \mathrm{r}_{\mathrm{i} 2} & \cdots & \mathrm{w}_{\mathrm{j}} \mathrm{r}_{\mathrm{ij}} & \cdots & \mathrm{w}_{\mathrm{n}} \mathrm{r}_{\mathrm{in}} \\
\vdots & \vdots & & \vdots & & \vdots \\
\mathrm{w}_{1} \mathrm{r}_{\mathrm{m} 1} & \mathrm{w}_{2} \mathrm{r}_{\mathrm{m} 2} & \cdots & \mathrm{w}_{\mathrm{j}} \mathrm{r}_{\mathrm{mj}} & \cdots & \mathrm{w}_{\mathrm{n}} \mathrm{r}_{\mathrm{mn}}
\end{array}\right]
\end{aligned}
$$

Determine the ideal solution and negative ideal solution: The ideal solution is computed based on the following equations:

$A^{*}=\left\{\left(\max V_{i j} \mid j \in J\right),\left(\min V_{i j} \mid j \in J^{\prime}\right), i=1,2, \ldots, m\right\}$

$A^{-}=\left\{\left(\min V_{i j} \mid j \in J\right),\left(\max V_{i j} \mid j \in J^{\prime}\right), i=1,2, \ldots, m\right\}$

Where:

$\mathrm{j}=\{\mathrm{j}=1,2, \ldots, \mathrm{n} \mid \mathrm{j}$ belongs to benefit criteria $\}$

$\mathrm{j}^{\prime}=\{\mathrm{j}=1,2, \ldots, \mathrm{n} \mid \mathrm{j}$ belongs to cost criteria $\}$

Calculate the distance between idea solution and negative ideal solution for each alternative:

$$
\mathrm{S}_{\mathrm{i}}^{*}=\sqrt{\sum_{\mathrm{j}=1}^{\mathrm{n}}\left(\mathrm{V}_{\mathrm{ij}}-\mathrm{V}_{\mathrm{j}}^{*}\right)^{2}} \mathrm{i}=1,2, \ldots, \mathrm{m}
$$




$$
\mathrm{S}_{\mathrm{i}}^{-}=\sqrt{\sum_{\mathrm{j}=1}^{\mathrm{n}}\left(\mathrm{V}_{\mathrm{ij}}-\mathrm{V}_{\mathrm{j}}^{-}\right)^{2}} \mathrm{i}=1,2, \ldots, \mathrm{m}
$$

Calculate the relative closeness to the ideal solution of each alternative:

$\mathrm{C}_{\mathrm{i}}^{*}=\frac{\mathrm{S}_{\mathrm{i}}^{-}}{\mathrm{S}_{\mathrm{i}}^{*}+\mathrm{S}_{\mathrm{i}}^{-}} \mathrm{i}=1,2, \ldots, \mathrm{m}$

where, $0 \leq C_{i}^{*} \leq 1$ that is, an alternative $\mathrm{i}$ is closer to $\mathrm{A}^{*}$ as $\mathrm{C}_{\mathrm{i}}^{*}$ approaches to 1 .

Rank the preference order: A set of alternatives can be preference ranked according to the descending order of $C_{i}^{*}$.

\section{RESULTS AND DISCUSSION}

\section{Case implementation:}

\section{Step 1:}

Establish an evaluate framework: Using the Delphi method $^{[13]}$, acquire evaluate framework; the evaluate framework are depicted in Fig. 3.

\section{Step 2:}

Determine the weight of criteria and sub-criteria by using AHP: The weights of criteria and

sub-criteria are then determined for a sample group of 19 individuals matching the above characteristics with each respondent making a pair-wise comparison of the decision criteria and sub-criteria assigning them relative scores. The relative scores provided by eleven experts are aggregated using the geometric mean method. The priorities for the criteria can be obtained by the procedure stated in the previous and is:

$$
\left.\begin{array}{ll}
\mathrm{C}_{1} & 0.292 \\
\mathrm{C}_{2} & 0.287 \\
\mathrm{C}_{3} & 0.220 \\
\mathrm{C}_{4} & 0.202
\end{array}\right]
$$

The respective weights of the four evaluative criteria are financial perspective (0.292), customer perspective (0.287), internal business process perspective $(0.220)$ and learning and growth perspective (0.202).

The eigenvectors for financial perspective, customer perspective, internal business process perspective and learning and growth perspective are organized into a matrix that represents the relative importance of sub-criteria with respect to their upper

\begin{tabular}{|c|c|c|c|c|}
\hline & $\mathrm{C}_{1}$ & $\mathrm{C}_{2}$ & $\mathrm{C}_{3}$ & $\mathrm{C}_{4}$ \\
\hline $\begin{array}{l}\mathrm{C}_{1} \\
C\end{array}$ & 0.243 & 0 & 0 & 0 \\
\hline $\begin{array}{l}\mathrm{SC}_{2} \\
\mathrm{SC}\end{array}$ & 0.171 & 0 & 0 & 0 \\
\hline $\begin{array}{l}\mathrm{SC}_{3} \\
\mathrm{SC}\end{array}$ & 0.430 & 0 & 0 & 0 \\
\hline $\begin{array}{l}\mathrm{SC}_{4} \\
\mathrm{SC}\end{array}$ & 0.156 & 0 & 0 & 0 \\
\hline & 0 & 0.103 & 0 & 0 \\
\hline & 0 & 0.140 & 0 & 0 \\
\hline & 0 & 0.502 & 0 & 0 \\
\hline $\begin{array}{l}\mathrm{SC}_{8} \\
\mathrm{CC}\end{array}$ & 0 & 0.110 & 0 & 0 \\
\hline $\mathrm{SL}_{9}$ & 0 & 0.145 & 0 & 0 \\
\hline $\begin{array}{l}\mathrm{SC}_{10} \\
\mathrm{SC}\end{array}$ & 0 & 0 & 0.128 & 0 \\
\hline $\begin{array}{l}\mathrm{SC}_{11} \\
\mathrm{SC}\end{array}$ & 0 & 0 & 0.192 & 0 \\
\hline $\begin{array}{l}\mathrm{SC}_{12} \\
\mathrm{SC}\end{array}$ & 0 & 0 & 0.279 & 0 \\
\hline $\begin{array}{l}\mathrm{SC}_{13} \\
\mathrm{SC}\end{array}$ & 0 & 0 & 0.171 & 0 \\
\hline $\begin{array}{l}\mathrm{SC}_{14} \\
\mathrm{SC}\end{array}$ & 0 & 0 & 0.230 & 0 \\
\hline $\begin{array}{l}\mathrm{SC}_{15} \\
\mathrm{SC}\end{array}$ & 0 & 0 & 0 & 0.402 \\
\hline $\begin{array}{l}\mathrm{SC}_{16} \\
\mathrm{SC}\end{array}$ & 0 & 0 & 0 & 0.209 \\
\hline $\begin{array}{l}\mathrm{SC}_{17} \\
\mathrm{SC}\end{array}$ & 0 & 0 & 0 & 0.094 \\
\hline $\begin{array}{l}\mathrm{SC}_{18} \\
\mathrm{SC}\end{array}$ & 0 & 0 & 0 & 0.182 \\
\hline & 0 & 0 & 0 & 0.112 \\
\hline
\end{tabular}
level criteria.
The respective weights of the four sub-criteria for financial perspective are $\mathrm{SC}_{1}(0.243), \mathrm{SC}_{2}(0.171)$, $\mathrm{SC}_{3}(0.430)$ and $\mathrm{SC}_{4}(0.156)$. The respective weights of the five sub-criteria for customer perspective are $\mathrm{SC}_{5}$ (0.103), $\mathrm{SC}_{6}(0.140), \mathrm{SC}_{7}(0.502), \mathrm{SC}_{8}(0.110)$ and $\mathrm{SC}_{9}(0.145)$. The respective weights of the five subcriteria for internal business process perspective are $\mathrm{SC}_{10}$ (0.128), $\mathrm{SC}_{11}$ (0.192), $\mathrm{SC}_{12}$ (0.279), $\mathrm{SC}_{13}$ (0.171) and $\mathrm{SC}_{14}(0.230)$. The respective weights of the five sub-criteria for learning and growth perspective are $\mathrm{SC}_{15}$ (0.402), $\mathrm{SC}_{16}$ (0.209), $\mathrm{SC}_{17}$ (0.094), $\mathrm{SC}_{18}$ (0.182) and $\mathrm{SC}_{19}$ (0.112). Assume there is no interdependence among sub-criteria, which sub-criteria should be, emphasized more in determining their respective upper level criterion.

Table 1, Synthesis Value (weights of overall) of four wealth management banks under nineteen subcriteria are $\mathrm{SC}_{1}$ (0.07), $\mathrm{SC}_{2}$ (0.05), $\mathrm{SC}_{3}$ (0.13), $\mathrm{SC}_{4}$ (0.05), $\mathrm{SC}_{5}$ (0.03), $\mathrm{SC}_{6}$ (0.04), $\mathrm{SC}_{7} \quad(0.14)$, $\mathrm{SC}_{8}$ (0.31), $\mathrm{SC}_{9}$ (0.04), $\mathrm{SC}_{10}(0.03), \mathrm{SC}_{11}$ (0.04), $\mathrm{SC}_{12}$ (0.06), $\mathrm{SC}_{13}$ (0.04), $\mathrm{SC}_{14}(0.05), \mathrm{SC}_{15}(0.08)$, $\mathrm{SC}_{16}$ (0.04), $\mathrm{SC}_{17}$ (0.02), $\mathrm{SC}_{18}$ (0.04) and $\mathrm{SC}_{19}$ (0.02). Customer Confidence $\left(\mathrm{SC}_{8}\right)$, customer profitability $\left(\mathrm{SC}_{7}\right)$ and ability to profitability $\left(\mathrm{SC}_{3}\right)$ are highly in 
Table 1: Eigenvectors (weights) for criteria and sub-criteria

\begin{tabular}{lllll}
\hline Criteria & $\begin{array}{l}\text { Weights } \\
\text { for level 2 }\end{array}$ & $\mathrm{Sub}_{\text {-criteria }}$ & $\begin{array}{l}\text { Weights } \\
\text { for level 3 }\end{array}$ & $\begin{array}{l}\text { Weights of } \\
\text { the overall }\end{array}$ \\
\hline $\mathrm{C}_{1}$ & 0.29 & $\mathrm{SC}_{1}$ & 0.24 & $0.07(5)$ \\
& & $\mathrm{SC}_{2}$ & 0.17 & $0.05(8)$ \\
& & $\mathrm{SC}_{3}$ & 0.43 & $0.13(3)$ \\
$\mathrm{C}_{2}$ & 0.29 & $\mathrm{SC}_{4}$ & 0.16 & $0.05(9)$ \\
& & $\mathrm{SC}_{5}$ & 0.10 & $0.03(16)$ \\
& & $\mathrm{SC}_{6}$ & 0.14 & $0.04(13)$ \\
& & $\mathrm{SC}_{7}$ & 0.50 & $0.14(2)$ \\
& & $\mathrm{SC}_{8}$ & 0.11 & $0.31(1)$ \\
$\mathrm{C}_{3}$ & $\mathrm{SC}_{9}$ & 0.15 & $0.04(12)$ \\
& 0.22 & $\mathrm{SC}_{5}$ & 0.13 & $0.03(17)$ \\
& & $\mathrm{SC}_{6}$ & 0.19 & $0.04(10-11)$ \\
& & $\mathrm{SC}_{7}$ & 0.28 & $0.06(6)$ \\
$\mathrm{S}_{4}$ & & $\mathrm{SC}_{8}$ & 0.17 & $0.04(14)$ \\
& & $\mathrm{SC}_{9}$ & 0.23 & $0.05(7)$ \\
& & $\mathrm{SC}_{15}$ & 0.40 & $0.08(4)$ \\
& & $\mathrm{SC}_{16}$ & 0.21 & $0.04(10-11)$ \\
& & $\mathrm{SC}_{17}$ & 0.09 & $0.02(19)$ \\
& & $\mathrm{SC}_{18}$ & 0.18 & $0.04(15)$ \\
& & $\mathrm{SC}_{19}$ & 0.11 & $0.02(18)$ \\
\hline
\end{tabular}

Step 3:

Determine the weight of organizational performance by using TOPSIS:

Establishing and normalizing the D matrix: At the next level of the decision procedure, 11 experts were asked to establish the decision matrix by comparing hospitals under each of the sub-criteria separately. The sub-criteria were assumed to be benefit sub-criteria and all the members were asked to give a set of crisp values within the range from 1-10 to represent the performance of each bank with respect to each sub-criterion. After the decision matrix was determined. Based on Table 2 normalize matrix by Eq. 5. Since the sub-criteria weights $\left(\mathrm{W}_{\mathrm{AHP}}\right)$ have been obtained from AHP, the weighted normalized performance matrix can be calculated by Eq. 6. Table 2-4 shows the decision, normalizes and weighted normalized matrix.

Determining the $\mathrm{C}_{\mathrm{i}}^{*}$ : First, determine the ideal solution and negative ideal solution using formulae (9) and (10). Table 5 displays those results. Next, calculate the relative closeness to the ideal solution of each alternative, $C_{i}^{*}$, using Eq. 11. According to Table 6 the ranking order of the four banks is Bank $\mathrm{C}(0.539)$, Bank A (0.482), Bank D (0.294) and Bank B (0.269). Therefore, the best organizational performance is Bank C.

Step 4: Final organizational performance score: Since the sub-criteria weights have been obtained from AHP, the TOPSIS weights can be calculated by Eq. 411. Table 6 summarizes those results. Summary of the performance with respect to organizational performance: Bank C (0.539), Bank A (0.482), Bank D (0.294) and Bank B (0.269). Bank C performs the best.

Table 2: The decision making matrix

\begin{tabular}{|c|c|c|c|c|c|c|c|c|c|c|c|c|c|c|c|c|c|c|c|}
\hline & $\mathrm{Sc}_{1}$ & $\mathrm{Sc}_{2}$ & $\mathrm{Sc}_{3}$ & $\mathrm{Sc}_{4}$ & $\mathrm{Sc}_{5}$ & $\mathrm{Sc}_{6}$ & $\mathrm{Sc}_{7}$ & $\mathrm{Sc}_{8}$ & $\mathrm{Sc}_{9}$ & $\mathrm{Sc}_{10}$ & $\mathrm{Sc}_{11}$ & $\mathrm{Sc}_{12}$ & $\mathrm{Sc}_{13}$ & $\mathrm{Sc}_{14}$ & $\mathrm{Sc}_{15}$ & $\mathrm{Sc}_{16}$ & $\mathrm{Sc}_{17}$ & $\mathrm{Sc}_{18}$ & $\mathrm{Sc}_{19}$ \\
\hline A & 0.15 & 0.26 & 023 & 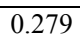 & 0 & 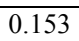 & 023 & 0.17 & 0.169 & 158 & 0.158 & 0.213 & - & 205 & 0.503 & 275 & 0.439 & 358 & 12 \\
\hline B & 0.15 & 0.260 & 0 & 0. & 0. & 0 & 0. & 0. & 177 & 07 & 0. & 0. & 7 & 1 & 44 & 299 & 8 & 222 & 0.136 \\
\hline $\mathrm{C}$ & 0.245 & 0.115 & 0.269 & 0.155 & 0.442 & 0.45 & 0.439 & 0.512 & 0.429 & 0.205 & 0.205 & 0.442 & 0.442 & 0.172 & 0.192 & 0.223 & 0.130 & 0.161 & 0.253 \\
\hline $\mathrm{D}$ & 0.446 & 0.357 & 0.249 & 0.266 & 0.147 & 0.257 & 0.170 & 0.148 & 0.224 & 0.330 & 0.330 & 0.147 & 0.147 & 0.172 & 0.141 & 0.202 & 0.242 & 0.259 & 0.098 \\
\hline
\end{tabular}

Table 3: The normalize decision making matrix

\begin{tabular}{lllllllllllllllllllll}
\hline & $\mathrm{Sc}_{1}$ & $\mathrm{Sc}_{2}$ & $\mathrm{Sc}_{3}$ & $\mathrm{Sc}_{4}$ & $\mathrm{Sc}_{5}$ & $\mathrm{Sc}_{6}$ & $\mathrm{Sc}_{7}$ & $\mathrm{Sc}_{8}$ & $\mathrm{Sc}_{9}$ & $\mathrm{Sc}_{10}$ & $\mathrm{Sc}_{11}$ & $\mathrm{Sc}_{12}$ & $\mathrm{Sc}_{13}$ & $\mathrm{Sc}_{14}$ & $\mathrm{Sc}_{15}$ & $\mathrm{Sc}_{16}$ & $\mathrm{Sc}_{17}$ & $\mathrm{Sc}_{18}$ & $\mathrm{Sc}_{19}$ \\
\hline $\mathrm{A}$ & 0.285 & 0.506 & 0.461 & 0.545 & 0.388 & 0.274 & 0.433 & 0.306 & 0.312 & 0.304 & 0.304 & 0.388 & 0.388 & 0.371 & 0.867 & 0.544 & 0.797 & 0.688 & 0.860 \\
$\mathrm{~B}$ & 0.273 & 0.491 & 0.501 & 0.584 & 0.359 & 0.251 & 0.279 & 0.275 & 0.326 & 0.591 & 0.591 & 0.359 & 0.359 & 0.817 & 0.283 & 0.591 & 0.341 & 0.427 & 0.228 \\
$\mathrm{C}$ & 0.442 & 0.217 & 0.537 & 0.303 & 0.805 & 0.806 & 0.799 & 0.875 & 0.791 & 0.394 & 0.394 & 0.805 & 0.805 & 0.312 & 0.331 & 0.441 & 0.236 & 0.310 & 0.425 \\
$\mathrm{D}$ & 0.805 & 0.675 & 0.497 & 0.520 & 0.268 & 0.460 & 0.310 & 0.253 & 0.413 & 0.635 & 0.635 & 0.268 & 0.268 & 0.312 & 0.243 & 0.400 & 0.439 & 0.498 & 0.165 \\
\hline
\end{tabular}

Table 4: The weighted normalize decision making matrix

\begin{tabular}{llllllllllllllllllll}
\hline & $\mathrm{Sc}_{1}$ & $\mathrm{Sc}_{2}$ & $\mathrm{Sc}_{3}$ & $\mathrm{Sc}_{4}$ & $\mathrm{Sc}_{5}$ & $\mathrm{Sc}_{6}$ & $\mathrm{Sc}_{7}$ & $\mathrm{Sc}_{8}$ & $\mathrm{Sc}_{9}$ & $\mathrm{Sc}_{10}$ & $\mathrm{Sc}_{11}$ & $\mathrm{Sc}_{12}$ & $\mathrm{Sc}_{13}$ & $\mathrm{Sc}_{14}$ & $\mathrm{Sc}_{15}$ & $\mathrm{Sc}_{16}$ & $\mathrm{Sc}_{17}$ & $\mathrm{Sc}_{18}$ & $\mathrm{Sc}_{19}$ \\
\hline $\mathrm{A}$ & 0.069 & 0.087 & 0.198 & 0.085 & 0.040 & 0.038 & 0.218 & 0.034 & 0.045 & 0.039 & 0.058 & 0.108 & 0.066 & 0.085 & 0.349 & 0.114 & 0.075 & 0.125 & 0.096 \\
$\mathrm{~B}$ & 0.066 & 0.084 & 0.216 & 0.091 & 0.037 & 0.035 & 0.140 & 0.030 & 0.047 & 0.076 & 0.113 & 0.100 & 0.061 & 0.188 & 0.114 & 0.124 & 0.032 & 0.078 & 0.026 \\
$\mathrm{C}$ & 0.108 & 0.037 & 0.231 & 0.047 & 0.083 & 0.113 & 0.401 & 0.096 & 0.115 & 0.050 & 0.076 & 0.225 & 0.138 & 0.072 & 0.133 & 0.092 & 0.022 & 0.056 & 0.048 \\
$\mathrm{D}$ & 0.196 & 0.115 & 0.214 & 0.081 & 0.028 & 0.064 & 0.155 & 0.028 & 0.060 & 0.081 & 0.122 & 0.075 & 0.046 & 0.072 & 0.098 & 0.084 & 0.041 & 0.091 & 0.018 \\
\hline
\end{tabular}

Table 5: Resultant of $\mathrm{S}_{\mathrm{i}}^{*}$ and $\mathrm{S}_{\mathrm{i}}^{-}$

\begin{tabular}{lll}
\hline & $\mathrm{S}_{\mathrm{i}}^{*}$ & $\mathrm{~S}_{\mathrm{i}}^{-}$ \\
\hline $\mathrm{A}$ & 0.321 & 0.299 \\
$\mathrm{~B}$ & 0.435 & 0.160 \\
$\mathrm{C}$ & 0.300 & 0.351 \\
$\mathrm{D}$ & 0.438 & 0.182 \\
\hline
\end{tabular}




\section{CONCLUSION}

The composite priorities of the alternatives are then determined by aggregating the weights throughout the hierarchy. The composite priorities of the alternatives are:

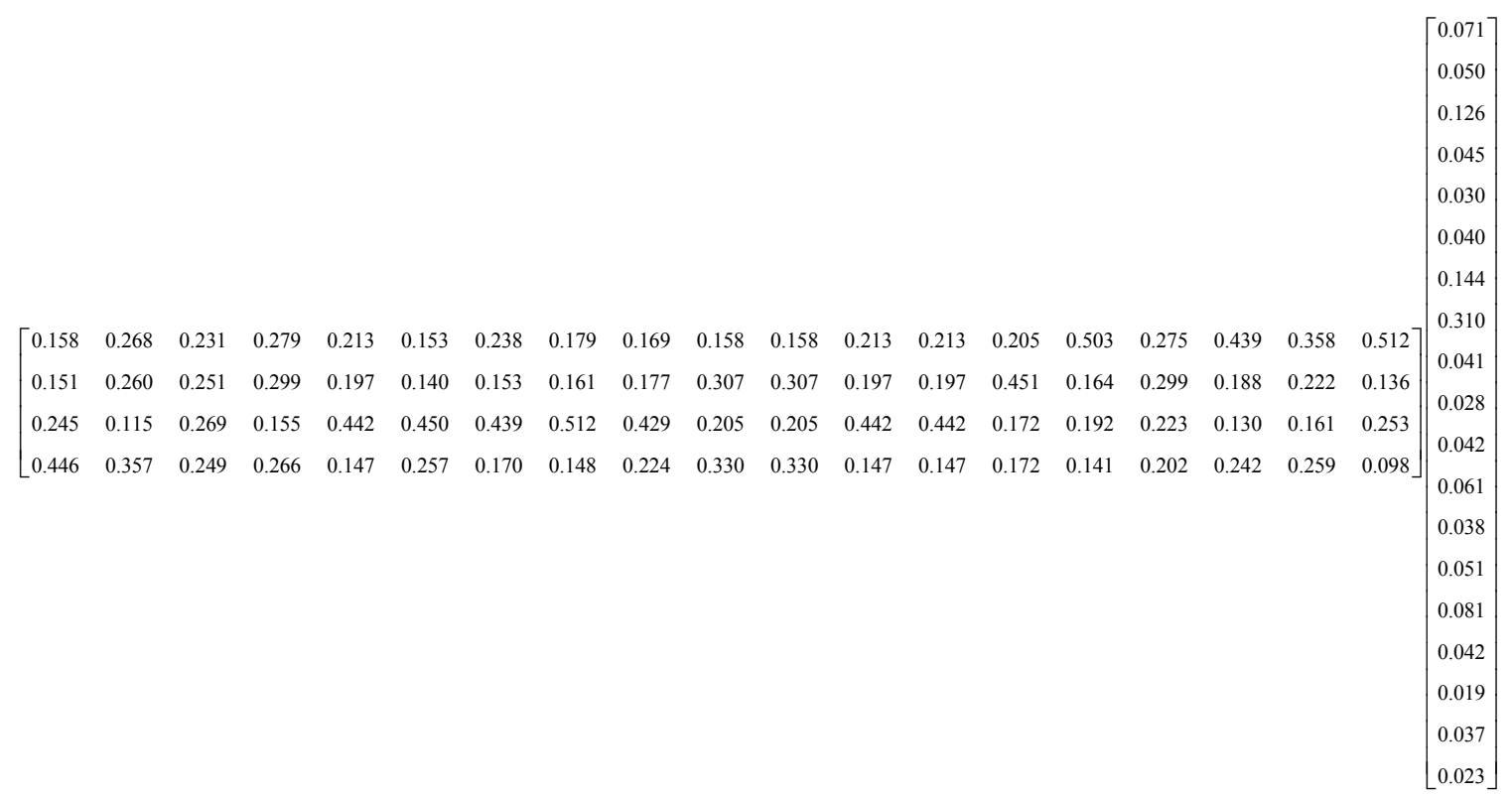

Formulae (14) indicate that the weights of AHP are as in the following:

Bank $\mathrm{A}=0.250$

Bank $\mathrm{B}=0.227$

Bank $\mathrm{C}=0.288$

Bank $\mathrm{D}=0.235$

Table 6: Summary of the TOPSIS $\mathrm{C}_{\mathrm{i}}{ }^{*}$

\begin{tabular}{lll}
\hline & $\mathrm{C}_{\mathrm{i}}^{*}$ & Rank \\
\hline $\mathrm{A}$ & 0.482 & 2 \\
$\mathrm{~B}$ & 0.269 & 4 \\
$\mathrm{C}$ & 0.539 & 1 \\
$\mathrm{D}$ & 0.294 & 3 \\
\hline
\end{tabular}

Table 7: Summary of the AHP

\begin{tabular}{lll}
\hline & Weights & Rank \\
\hline A & 0.250 & 2 \\
B & 0.227 & 4 \\
C & 0.288 & 1 \\
D & 0.235 & 3 \\
\hline
\end{tabular}

Table 8: Comparison of the findings of AHP and TOPSIS AHP TOPSIS

\begin{tabular}{llllll}
\hline OP & Results & Rank & OP & Results & Rank \\
\hline A & 0.250 & 2 & A & 0.482 & 2 \\
B & 0.227 & 4 & B & 0.269 & 4 \\
C & 0.288 & 1 & C & 0.539 & 1 \\
D & 0.235 & 3 & D & 0.294 & 3 \\
\hline
\end{tabular}

Therefore, Bank $\mathrm{C}$ performs the best, Table 7 summary of AHP.

The purpose of this study is to present an effective framework applying both AHP and TOPSIS methods to evaluate organizational performance of wealth management banks. In order to ascertain the value of this model, results of the normalized relative weights of the organizational performance of wealth management banks obtained from AHP and TOPSIS are compared. Table 6 shows the relative weights of the four banks based on the results of from AHP, as well as the relative weights from TOPSIS. In the demonstrated example, Bank $\mathrm{C}$ should be perfect because it has the largest relative weights (Bank $\mathrm{C}=0.288$ and 0.539 , from AHP and TOPSIS in Table 8).

In Table 6, Summary of the TOPSIS $\mathrm{C}_{\mathrm{i}}^{*}$ with respect to wealth management banks: A (0.482), B (0.269), C (0.539) and D (0.294). C performs the best. Therefore, the administrators or decision makers should select C. Finally, we recommend that administrators or decision makers can use this model to evaluate the organizational performance of wealth management banks for bank administrators and financial sector analysts. 


\section{REFERENCES}

1. Chang, C.W., C.R. Wu and H.C. Chen, 2008. Using expert technology to select unstable slicing machine to control wafer slicing quality via fuzzy AHP. Int. J. Expert Syst. Appl., 34: 2210-2220. http://portal.acm.org/citation.cfm?id=1327791.

2. Hwang, C.L. and K. Yoon, 1981. Multiple Attribute Decision Making: Methods and Application. 1st Edn., Springer-Verlag, New York, USA., pp: 259. ISBN: 10: 0387105581.

3. Javalgi, R.G., R.L. Armacost and J.C. Hosseini, 1989. Using the analytic hierarchy process for bank management: Analysis of consumer bank selection decisions. J. Bus. Res., 19: 33-49. http://ideas. repec.org/a/eee/jbrese/v19y1989ilp33-49.html.

4. Johnson, H.T. and R.S. Kaplan, 1987. Relevance Lost, the Rise and Fall of Management Accounting. 1st Edn., Harvard Business School Press, Boston, MA., ISBN: 0875841384, pp: 269.

5. Kaplan, R.S. and D.P. Norton, 1992. The balanced scorecard: Measures that drive performance. Harvard Bus. Rev., 70: 71-79. http://en.wikipedia.org/wiki/Balanced_scorecard.

6. Kaplan, R.S. and D.P. Norton, 1993. Putting the balanced scorecard to work. Harvard Bus. Rev., 71: 134-142. http://harvardbusinessonline.hbsp.harvard.edu/b02/ en/common/item_detail.jhtml?id=93505

7. Kaplan, R.S. and D.P. Norton, 1994. Devising a balanced scorecard matched to business strategy. Plann. Rev., 22: 15-48. DOI: 10.1108/eb054476.

8. Kaplan, R.S. and D.P. Norton, 1996. Using the balanced scorecard as a strategic management system. Harvard Bus. Rev., 74: 75-85. http://portal.sfusd.edu/data/strategicplan/Harvard\% 20Business\%20Review\%20article\%20BSC.pdf.

9. Kaplan, R.S. and D.P. Norton, 1996. The Balanced Scorecard: Translating Strategy into Action. 1st Edn., Harvard Business School Press, Boston, ISBN: 10: 0875846513, pp: 322.

10. Kaplan, R.S. and D.P. Norton, 1996. Strategic learning and the balanced scorecard. Strategy Leadership, 24: 18-24. DOI: 10.1108/eb0545566.
11. Saaty, T.L., 1980. The Analytic Hierarchy Process. 1st Edn., McGraw Hill Publications, New York, USA., ISBN: 10: 0070543712 pp: 287.

12. Saaty, T.L., 1990. How to mark a decision: The analytic hierarchy process. Eur. J. Operat. Res., 48: $\quad 9-26$. http://sigma.poligran.edu.co/politecnico/apoyo/Dec isiones/curso/Interfaces.pdf.

13. Wu, C.R., C.T. Lin and H.C. Chen, 2007a. Optimal selection of location for Taiwanese hospitals to ensure a competitive advantage by using the Analytic Hierarchy Process and Sensitivity analysis. Build. Environ., 42: 1431-1444. http://cat.inist.fr/?aModele $=$ afficheN\&cpsidt $=1840$ 2958.

14. Wu, C.R., C.W. Chang and H.L. Lin 2007b. FAHP sensitivity analysis for measurement nonprofit organizational performance. Qual. Quant., 42: 283302. DOI: $10.1007 / \mathrm{s} 11135-006-9046-2$.

15. Wu, C.R., C.T. Lin and H.C. Chen, 2007c. Integrated environmental assessment of the location selection with fuzzy analytical network process. Qual. Quant., 41: DOI: 10.1007/s11135007-9125-z.

16. Bertolinin, M. and M. Bevilacqua, 2006. A combined goal programming-AHP approach to maintenance selection problem. Reliabi. Eng. Sys. Safe., $\quad$ 91: $\quad 839-848$. DOI:10.1016/j.ress.2005.08.006

17. Ramanathan, R. and L.S. Ganesh, 1995. Using AHP for resource allocation problems. Eur. J. Operat. Res., 80: 410-417. DOI: 10.1016/03772217(93)E0240-X

18. Zeng, G., R. Jiang, G. Huang, M. Xu and J. Li, 2007. Optimization of wastewater treatment alternative selection by hierarch grey relational analysis. J. Environ. Manage., 82: 250-259. DOI: 10.1016/j.jenvman.2005.12.024.

19. Saaty, T.L., 2000. Fundamentals of decision making and priority theory with the analytic hierarchy process, Pittsburgh: RWS Publications, ISBN: 0-9620317-6-3, pp: 478. 